\title{
Type II diabetes and impaired glucose tolerance due to severe hyperinsulinism in patients with 1 p36 deletion syndrome and a Prader-Willi-like phenotype
}

\author{
Stefano Stagi ${ }^{1,4^{*}}$, Elisabetta Lapi ${ }^{2}$, Marilena Pantaleo ${ }^{2}$, Francesco Chiarelli ${ }^{3}$, Salvatore Seminara ${ }^{1}$ \\ and Maurizio de Martino ${ }^{1}$
}

\begin{abstract}
Background: Deletion of the subtelomeric region of $1 \mathrm{p} 36$ is one of the most common subtelomeric deletion syndromes. In monosomy $1 \mathrm{p} 36$, the presence of obesity is poorly defined, and glucose metabolism deficiency is rarely reported. However, the presence of a typical Prader-Willi-like phenotype in patients with monosomy 1 p36 is controversial.

Case presentation: In this report, we describe two female patients, one who is 6 years 2 months of age and another who is 10 years 1 month of age, both referred to our hospital for obesity and a Prader-Willi-like phenotype. These patients presented with severe obesity (body mass index [BMI] was 26.4 and 27.7, respectively), hyperphagia and developmental delay. Analysis of basal hormone levels showed normal thyroid function and adrenal function but considerable basal hyperinsulinism (the insulin levels were 54.5 and $49.2 \mu \mathrm{U} / \mathrm{ml}$, respectively). In patient 1, glycaemia was $75 \mathrm{mg} / \mathrm{dl}$ (HOMA-R 10.09), and the HbA1c level was 6.1\%; in patient 2, glycaemia was $122 \mathrm{mg} / \mathrm{dl}$, and the HbA1c level was 6.6\% (HOMA-R 14.82). An oral glucose tolerance test demonstrated impaired glucose tolerance and diabetes mellitus with marked insulin resistance (the peak insulin level for each patient was 197 and $279 \mu \mathrm{U} / \mathrm{mL}$, respectively, while the 120' insulin level of each patient was 167 and $234 \mu \mathrm{U} / \mathrm{mL}$, respectively).
\end{abstract}

Conclusion: some patients with monosomy 1 p36 may show Prader-Willi-like physical and physiologic characteristics such as obesity and hyperinsulinism with impaired glucose metabolism, which can cause type II diabetes mellitus. Further studies are necessary to evaluate these findings.

Keywords: Monosomy 1p36, Deletion 1p36, Developmental delay, Mental retardation, Seizures, Obesity, Hyperinsulinism, Impaired glucose tolerance, Hyperphagia, Prader-Willi-like phenotype

\section{Background}

Deletion of the subtelomeric region of $1 \mathrm{p} 36$ is one of the most common subtelomeric deletion syndromes, with an estimated incidence of 1 in 5000 to 1 in 10,000 live births [1-3]. The four classes of rearrangements identified in individuals with monosomy $1 \mathrm{p} 36$ in order of frequency are as follows: apparently pure/simple terminal deletions (67\%), derivative chromosomes (16\%),

\footnotetext{
* Correspondence: stefano.stagi@yahoo.it

'Health's Sciences Department, University of Florence, Anna Meyer Children's University Hospital, Florence, Italy

${ }^{4}$ Paediatric Endocrinology Unit, Anna Meyer Children's University Hospital, viale Pieraccini 24, Florence 50139, Italy

Full list of author information is available at the end of the article
}

interstitial deletions (10\%), and complex rearrangements (7\%) [4].

Monosomy $1 \mathrm{p} 36$ is responsible for a cluster of characteristic clinical features including mental retardation and multiple congenital abnormalities caused by haploinsufficiency of numerous contiguous genes [1], such as deep-set eyes, straight eyebrows positioned low on the supra-orbital ridges, asymmetric ears, a pointed chin, and a flat nasal bridge [1]. Additional features include cardiomyopathy, hearing impairment, seizures $[5,6]$, and a variety of neoplasms due to the loss of numerous tumour-suppressor genes that are located in this chromosomal region $[7,8]$.

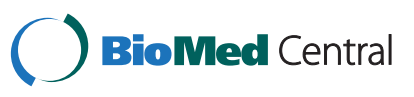

(c) 2014 Stagi et al.; licensee BioMed Central Ltd. This is an Open Access article distributed under the terms of the Creative Commons Attribution License (http://creativecommons.org/licenses/by/2.0), which permits unrestricted use, distribution, and reproduction in any medium, provided the original work is properly credited. 
In monosomy $1 \mathrm{p} 36$, the occurrence of both obesity and or glucose metabolism disorders is rarely reported. However, the presence of a typical Prader-Willi-like phenotype in patients with 1 p36 monosomy is controversial.

\section{Case presentation}

In this report, we describe two female subjects with monosomy 1 p36 and Prader-Willi-like phenotype who also exhibit type II diabetes and impaired glucose tolerance due to hyperinsulinism. We provide data both for and against this possible association. Written informed consent was obtained from the parents before publication of this case report and any accompanying images.

\section{Clinical report 1}

A female patient, 6 years 2 months of age, was referred to our Paediatric Endocrinology Unit for severe obesity.

The proposita was the third-born child (the first pregnancy was interrupted because of a disorder involving chromosome 7) of a nonconsanguineous marriage who was delivered normally at 40 weeks after an uncomplicated pregnancy. The family history was unremarkable, particularly for obesity, which was present only in a paternal uncle. The Apgar score was $5^{\mathrm{I}}-7^{\mathrm{V}}-8^{\mathrm{X}}$, and the infant required oral and gastric suctioning, as well as oxygen and stimulation upon delivery to treat cyanosis. Birth weight was $2.175 \mathrm{~kg}\left(-2.67 \mathrm{SDS} ;<3^{\text {rd }}\right.$ centile), length was $44 \mathrm{~cm}$ (-2.92 SDS; $<3^{\text {rd }}$ centile), and head circumference was $32 \mathrm{~cm}\left(-2.01 \mathrm{SDS} ;<3^{\text {rd }}\right.$ centile). The neonatal screening for congenital hypothyroidism was negative.

She presented with abnormal psychomotor development, as she sat upright at 8 months, began to walk independently at 15 months and began to use language at 15 months.

At 6 yrs, 2 months of age, this patient weighed $32.000 \mathrm{~kg}$ (1.73 SDS; >>97 ${ }^{\text {th }}$ centile), her height was $110 \mathrm{~cm}(-1.34$ SDS; $3-10^{\text {th }}$ centile), and her occipital-frontal circumference was $45.8 \mathrm{~cm}\left(-2.65 \mathrm{SDS} ;<3^{\text {rd }}\right.$ centile). This patient's BMI was 26.4 (2.41 SDS; $>>97^{\text {th }}$ centile), and the pubertal staging was defined as B1-PH2-3-AH2. Her blood pressure evaluation showed both systolic and diastolic hypertension (124/85 $\mathrm{mmHg}$ ).

Numerous dysmorphic features were observed, including a small mouth with heaped-up palate, a small chin, a small folded ear, straight eyebrows, fifth finger clinodactyly and short toes. Examination of the subject's mother revealed some mild dysmorphism, clinodactyly of the fifth finger and a mild learning disability (Figure 1a; Table 1).

Assessment of basal hormone levels showed normal free thyroxine (1.63 ng/dL; range 0.8-1.9), TSH (3.51 $\mu \mathrm{IU} / \mathrm{mL}$; range, 0.4-4.0), cortisol (12.3 $\mu \mathrm{g} / \mathrm{dL}$; range 5-19) and ACTH (21.1 ng/L; range 9.0-52.0) values. The blood count was also normal. Her blood chemistry was AST: 45 IU/L, ALT:

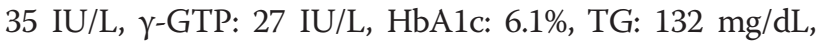

total cholesterol: $195 \mathrm{mg} / \mathrm{dL}, \mathrm{HDL}: 51 \mathrm{mg} / \mathrm{dL}$, insulin: 54.5 $\mu \mathrm{U} / \mathrm{ml}$, glycaemia: $102 \mathrm{mg} / \mathrm{dl}$ (HOMA 13.72). A screening for coeliac disease was negative (IgA $142 \mathrm{mg} / \mathrm{dl}$; tTG $0.2 \mathrm{U} /$ $\mathrm{mL}$ ), but an oral glucose tolerance test indicated hyperinsulinism (peak insulin level was $297 \mu \mathrm{U} / \mathrm{mL}$ ), impaired glucose tolerance (120' glycaemia $179 \mathrm{mg} / \mathrm{dl})$, and marked insulin resistance (120' insulin level $193 \mu \mathrm{U} / \mathrm{mL})$.

Routine cytogenetic investigations revealed an apparently normal female karyotype (46, XX). Chromosomal studies, also using FISH, ruled out a 15q11.2-q13 deletion. Tests for methylation and the presence of maternal uniparental disomy were both negative.

Given the numerous clinical features observed in this subject, a FISH analysis utilising 41 subtelomere probes was performed (Genzyme laboratories (Hawthorne, NY)) using Vysis probes (Downers Grove, IL). The results were confirmed with a chromosome 1p subtelomere probe (1pSUBTEL; Vysis) and the D1Z2 midi-satellite probe with repeats in band 1p36 (Oncor), which is used to confirm a common deletion interval (1p36.3).

Molecular karyotyping was performed by an array-CGH analysis using the proband's DNA and an Agilent $44 \mathrm{~K}$ array platform with a resolution of approximately $100 \mathrm{~kb}$. Based on the physical mapping positions designated in the March 2006 assembly (NCBI36/hg18) of the UCSC Genome Browser, this analysis showed a deletion of approximately $1.5 \mathrm{Mb}$ that involved the $1 \mathrm{p} 36.33$ region, with the breakpoint falling between 554,268 bp (first-deleted oligomer) and 2,133,973 bp (last-deleted oligomer) (Figure 2a).

\section{Clinical report 2}

The female patient, 10 years 1 month of age, was referred to the Genetics and Molecular Medicine Unit of Anna Meyer Children's University Hospital for severe obesity and suspected Prader-Willi syndrome.

The proposita was the second-born child of a nonconsanguineous marriage who was delivered normally at 39 weeks after an uncomplicated pregnancy. The family history was unremarkable in terms of obesity. The patient has a brother with normal staturo-ponderal growth who was 6 yrs old at the time of this study.

The Apgar score was $6^{\mathrm{I}}-9^{\mathrm{V}}-9^{\mathrm{X}}$; as an infant, she required oral suctioning, oxygen and stimulation at delivery for treatment of cyanosis. Her birth weight was $2.360 \mathrm{~kg}$ $\left(-1.92 \mathrm{SDS} ;<3^{\text {rd }}\right.$ centile), her length was $44.6 \mathrm{~cm}(-2.24$ SDS; $<3^{\text {rd }}$ centile), and her head circumference was $32 \mathrm{~cm}\left(-1.90 \mathrm{SDS} ;<3^{\text {rd }}\right.$ centile). Central hypotonia occurred soon after birth. The screening for neonatal congenital hypothyroidism was negative, but she experienced recurrent respiratory infections throughout the first year of life.

At 6 months of age, persistence of patent ductus arteriosus (PDA), which lead to pulmonary hypertension, was diagnosed; PDA was closed at 7 months. She presented 

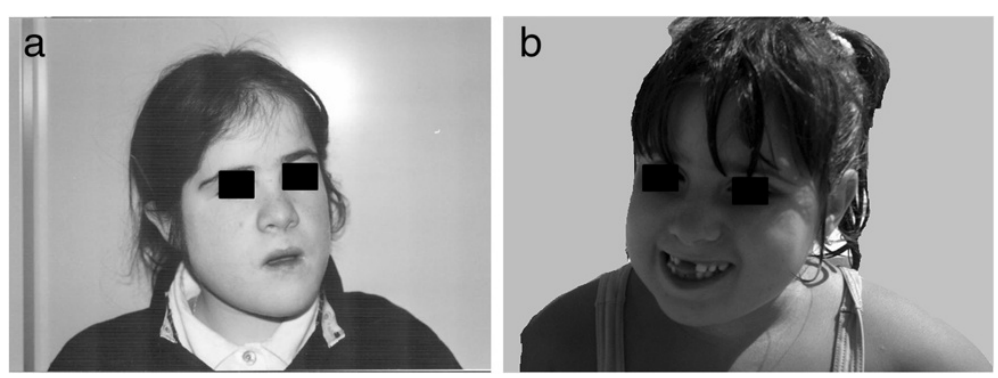

Figure 1 Case 1 at 4 years 2 months of age (1a), and case 2 at 6 years 8 months of age (1b). In these patients, there is evidence of some of the typical facial dysmorphisms of 1 p36 deletion syndrome with Prader-Willi-like phenotype.

Table 1 Clinical findings in patients with 1 p36 deletion syndrome and Prader-Willi-like phenotype

\begin{tabular}{|c|c|c|c|c|c|c|c|}
\hline Clinical findings & $\begin{array}{c}\text { Case } \\
1\end{array}$ & $\begin{array}{c}\text { Case } \\
2\end{array}$ & $\begin{array}{l}\text { D'Angelo et al., } \\
2006 \text { [11] }\end{array}$ & $\begin{array}{l}\text { D'Angelo } \\
\text { et al., } 2010 \text { [23] }\end{array}$ & $\begin{array}{c}\text { Eugster et al., } \\
1997 \text { [21] }\end{array}$ & $\begin{array}{c}\text { Tsuyusaki } \\
\text { et al., } 2010 \text { [24] }\end{array}$ & $\begin{array}{c}\text { Tsuyusaki } \\
\text { et al., } 2010 \text { [24] }\end{array}$ \\
\hline Microcephaly & + & + & - & - & - & - & - \\
\hline Brachycephaly & + & + & - & - & + & - & - \\
\hline Straight eyebrows & + & + & + & + & & + & + \\
\hline Deep-set eyes & + & + & $+/-$ & $+/-$ & + & + & + \\
\hline Epicanthal folds & + & + & - & - & - & - & - \\
\hline Broad nasal root/bridge & + & + & - & - & + & + & - \\
\hline Posteriorly rotated/low-set/abnormal ears & + & + & - & - & - & + & - \\
\hline Pointed chin & + & + & - & - & + & + & - \\
\hline Midface hypoplasia & + & + & - & - & + & + & + \\
\hline Short feet & + & + & + & + & + & + & + \\
\hline Developmental delay & + & + & + & + & + & + & + \\
\hline Mental retardation & + & + & + & + & + & + & + \\
\hline Hypotonia & + & + & + & + & + & + & + \\
\hline Seizures & + & + & - & - & + & + & + \\
\hline Brain abnormalities & - & - & & & - & + & + \\
\hline Sensorineural deafness & $+/-$ & $+/-$ & - & - & + & $+/-$ & - \\
\hline Strabismus & + & + & - & - & + & - & - \\
\hline Expressive language (poor/absent) & + & + & + & + & + & + & + \\
\hline Behavioural disorders & + & + & + & + & + & + & + \\
\hline Heart abnormalities & - & - & - & - & ND & + & - \\
\hline Renal abnormalities & - & - & - & - & ND & - & - \\
\hline External genitalia abnormalities & - & - & - & - & ND & - & - \\
\hline Poor neonatal weight & + & + & + & + & $+/-$ & + & - \\
\hline Poor neonatal length & + & + & + & + & ND & - & + \\
\hline Hyperphagia & + & + & + & + & + & + & + \\
\hline Obesity & + & + & + & + & + & + & + \\
\hline Hyperinsulinism & + & + & ND & ND & ND & ND & ND \\
\hline Thyroid disorders & - & - & + (thyroid nodules) & + & ND & ND & ND \\
\hline
\end{tabular}

$+=$ present.

$-=$ not present.

$\mathrm{ND}=$ not determined 


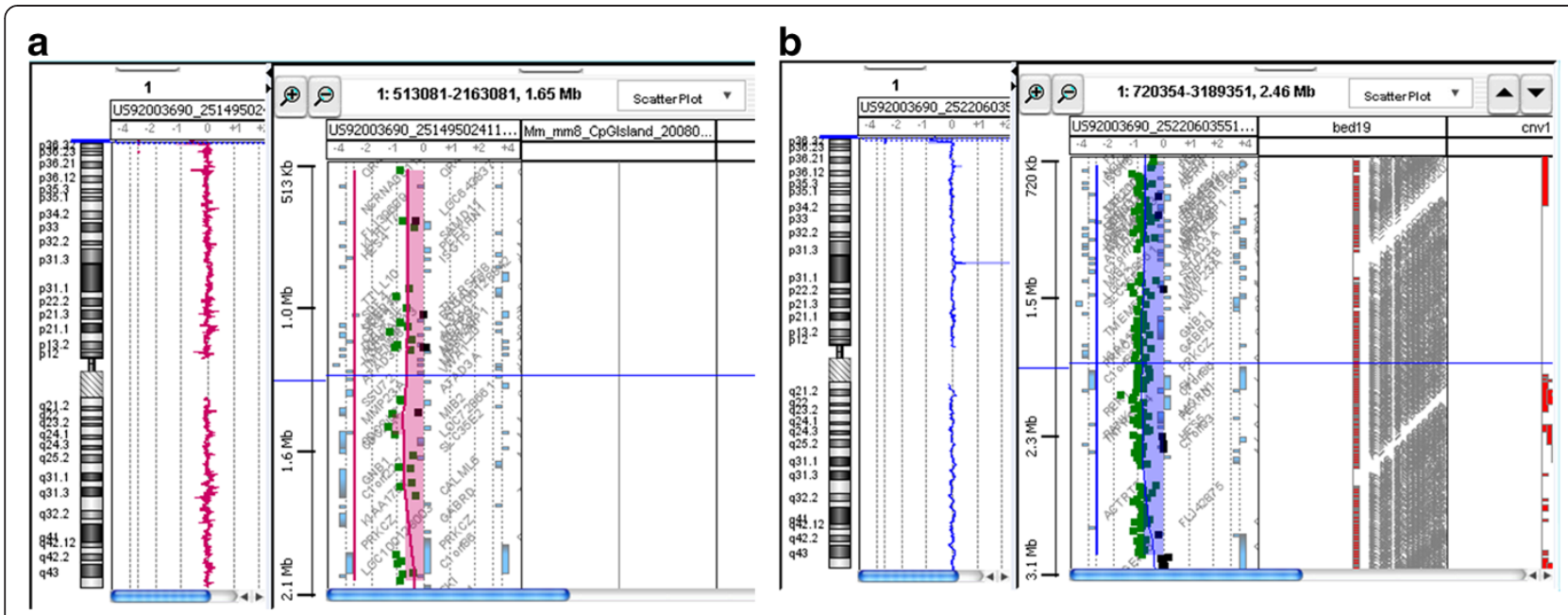

Figure 2 Array-CGH analysis showing a deletion of approximately $1.5 \mathrm{Mb}$ that involved the $1 \mathrm{p} 36.33$ region, with the breakpoint falling between $554,268 \mathrm{bp}$ and 2,133,973 bp (2a), and a deletion of approximately $2.5 \mathrm{Mb}$ that involved the $1 \mathrm{p} 36.33-1 \mathrm{p} 36.32$ region, with the breakpoint falling between 564,424 bp and 3,111,905 bp (2b).

with abnormal psychomotor development, as she began to sit upright at 9 months, walk independently at 17 months and demonstrated use of language at 19 months. Bilateral neurosensory deafness was diagnosed at 1 year of age. The child developed significant hyperphagia.

At 10 yrs 1 month of age, the proposita showed a phenotype consistent with Prader-Willi syndrome: the patient weighed $52.600 \mathrm{~kg}$ (1.65 SDS; 90-97 ${ }^{\text {th }}$ centile), her length was $131.8 \mathrm{~cm}\left(-1.18 \mathrm{SDS} ; 10^{\text {th }}\right.$ centile), and her BMI was 27.7 (2.02 SDS; >>97 ${ }^{\text {th }}$ centile). The pubertal staging was defined as B1-PH2-3-AH2. Blood pressure evaluation showed systolic and diastolic hypertension (124/85 mmHg).

At the evaluation, she was observed to have numerous dysmorphic features, including substantial truncular obesity, scoliosis, small hands and feet, a small mouth with heaped-up palate, a small chin and a small folded ear, straight eyebrows, fifth finger clinodactyly and short toes, and a mild learning disability. Examination of the mother revealed some mild dysmorphism, clinodactyly of the fifth finger, and a mild learning disability (Figure 1b).

An analysis of basal hormone levels showed normal free thyroxine $(13.7 \mathrm{pmol} / \mathrm{L}$; range $10.3-19.4 \mathrm{pmol} / \mathrm{L})$, TSH (2.6 mIU/L; range, 0.4-4.0), cortisol (14.1 ug/dL; range 5.0-19.0) and ACTH 14.1 (range 9.0-52.0 ng/L) values. The blood count was also normal, and her blood chemistry was as follows: AST: $20 \mathrm{IU} / \mathrm{L}, \mathrm{ALT}: 21 \mathrm{IU} / \mathrm{L}$, $\gamma$-GTP: $32 \mathrm{IU} / \mathrm{L}, \mathrm{HbA1c}: 5.5 \%$, TG: $146 \mathrm{mg} / \mathrm{dL}$, total cholesterol: $259 \mathrm{mg} / \mathrm{dL}$, HDL: $45 \mathrm{mg} / \mathrm{dL}$, prolactin: 271 $\mathrm{mIU} / \mathrm{L}$, HbA1c: 6.6\%, insulin: $49.2 \mu \mathrm{U} / \mathrm{ml}$, glycemia $122 \mathrm{mg} / \mathrm{dl}$ (HOMA-R 14.82). The screening for coeliac disease was negative (IgA $165 \mathrm{mg} / \mathrm{dl}$; tTG $0.4 \mathrm{U} / \mathrm{mL}$ ), and an oral glucose tolerance test indicated diabetes mellitus (120' glycaemia $234 \mathrm{mg} / \mathrm{dl}$ ), with marked hyperinsulinism and insulin resistance (peak insulin level was $279 \mu \mathrm{U} / \mathrm{mL}, 120$ ' insulin level $167 \mu \mathrm{U} / \mathrm{mL}$ ).

Routine cytogenetic investigations revealed an apparently normal female karyotype (46, XX). Chromosomal studies, which also used FISH, ruled out a 15q11.2-q13 deletion found in Prader-Willi syndrome. The hypophyseal RMN revealed an empty sella.

At 12 yrs, 8 months, her height was $141 \mathrm{~cm}(-2.10$ SDS $;<3^{\text {rd }}$ centile), BMI was 29.9 (2.18 SDS; $>97^{\text {th }}$ centile), and pubertal staging was described as B2-3-PH4AH2. Menarche started at 13 years of age.

At 16 years of age, her height was $145 \mathrm{~cm}(-2.82 \mathrm{SDS}$; < $3^{\text {rd }}$ centile), her weight was $56.000 \mathrm{~kg}\left(0.05\right.$ SDS; $50-75^{\text {th }}$ centile), and pubertal staging was found to be B5-PH5AH3.

Tests for methylation and the presence of maternal uniparental disomy were both negative. Therefore, given the numerous clinical features observed in this subject, a FISH analysis utilising 41 subtelomere probes was performed (Genzyme laboratories (Hawthorne, NY), using Vysis probes (Downers Grove, IL). The results were confirmed with a chromosome 1p subtelomere probe (1pSUBTEL; Vysis) and the D1Z2 midi-satellite probe with repeats in band $1 \mathrm{p} 36$ (Oncor). The D1Z2 probe is used for the confirmation of a common deletion interval (1p36.3). ArrayCGH was performed using the Agilent Human Genome CGH microarray kit $180 \mathrm{~K}$, with a resolution of approximately $40 \mathrm{~kb}$. Break point positions were reported according to Hg19, with build 37 falling between 564,424 bp (first-deleted oligomer) and 3,111,905 bp (last-deleted oligomer), which showed a deletion of approximately $2.5 \mathrm{Mb}$ that involved the $1 \mathrm{p} 36.33-1 \mathrm{p} 36.32$ region (Figure $2 \mathrm{~b}$ ). 


\section{Conclusion}

Monosomy $1 \mathrm{p} 36$ is a common deletion syndrome that produces specific physical characteristics, such as distinctive facial anomalies (pointed chin, flat nose, low-set ears), cardiovascular malformations (atrial septal defect, patent ductus arteriosus, tetralogy of Fallot), central nervous system defects (mental retardation, cranial nerve abnormalities, sensorineural hearing loss), neonatal hypotonia, cortical dysplasia, and seizures $[2,9,10]$. Affected individuals can display outbursts, a tendency towards violent and self-injurious behaviour, as well as autistic-like behaviours [5].

In patients with monosomy $1 \mathrm{p} 36$, the presence of obesity has been poorly defined, and glucose metabolism disorders have been infrequently reported to date. For example, D'Angelo et al. [11] identified 1 case of diabetes in a 13-year old patient, from within a group of 41 patients with a Prader-Willi-like phenotype, who had a pure 1 p36 deletion. However, a study that evaluated the glucose metabolism in subjects with $1 \mathrm{p} 36$ deletion syndrome had not been performed until our current study.

Our case reports confirm this association and suggest that this phenotype may be associated with obesity in some 1 p36 patients. We also present evidence that hyperinsulinism and impaired glucose tolerance or diabetes mellitus may be present in these patients and that these features can occur in younger patients.

In fact, genome-wide linkage studies suggest that the 1 p36 region shows a strong correlation with several traits normally associated with metabolic syndrome (MetS) [12], such as hyperlipidaemia, diabetes, obesity, arterial hypertension, and BMI cluster $[13,14]$.

Prader-Willi-like phenotype has been described in patients with chromosomal duplications [15,16], Fragile X syndrome [17], udp(14)mat $[18,19]$, and 6q deletion syndrome [20].

Obesity and/or hyperphagia are features rarely described in patients with 1p 36 deletion [1,11,21-24], but correlations between the extents of the deleted chromosomal segments have not been comprehensively provided. A hypothesis for the similarity between patients with a 1p36 deletion and those with Prader-Willi syndrome, as well as for the existence of two different phenotypes for a 1p36 microdeletion, has been suggested [23]. Contrary to its manifestation in 1 p36 deletion syndrome, obesity is a common clinical sign associated with mental retardation, and is clearly a public health problem. Thus, a suitable question to ask is whether these patients, who were described as being obese, are really representative of this particular deletion syndrome [25].

To help paediatric neurologists and other professionals in the recognition of this emerging and common chromosomal syndrome and to identify the possible overlap of clinical presentations between patients with 1p36 deletion syndrome and patients with a Prader-Willi like phenotype, we have reviewed published articles that describe patients with these features.

D'angelo et al. [23] described samples from 26 patients with Prader-Willi-like phenotype that were analysed with a 1p-specific subtelomeric probe, where one terminal deletion was identified in one patient. This patient did not have any of the obvious features that resembled this monosomy, but her clinical and behavioural features were quite similar to those observed in patients with PWS, except for the presence of normal sucking at birth. The extent of the deletion could be limited to the mostterminal $2.5 \mathrm{Mb}$ of $1 \mathrm{p} 36$, within the chromosomal region $1 \mathrm{p} 36.33-1 \mathrm{p} 36.32$, that is smaller than that usually observed in monosomy $1 \mathrm{p} 36$ patients. Slavotinek et al. [5] reviewed 39 cases reported to have pure 1 p36 deletions and 2 cases (5.1\%) that demonstrated the PraderWilli-like phenotype. Shapira et al. [1] described 13 cases of the pure $1 \mathrm{p} 36$ deletion and found 2 cases (15\%) of obesity. Therefore, chromosome 1p36.33 deletion should be investigated in patients with hypotonia, developmental delay, obesity and/or hyperphagia and behavioural problems who test negative for PWS, which might suggest non-classical manifestations of this disorder in these patients [23].

Thus far, no individual gene within this region has been conclusively determined to be causative of any component of the phenotype [23]. However, in patients with 1 p36 deletion syndrome and PWS-like phenotype, the possible involvement of the terminal $4 \mathrm{Mb}$ of chromosome 1 p36 may be postulated [24].

Interestingly, D'Angelo et al. [23] have found that some genes located near $1 \mathrm{p} 36$ may be involved in carbohydrate or lipid metabolism or insulin signalling. Some of these genes may be implicated in the Prader-Willi-like phenotype typical of some monosomy $1 \mathrm{p} 36$ patients through a mechanism of either haploinsufficiency, position effect or gene interactions (epistasis) [23]. This may be important because the $1 \mathrm{p} 34-36$ region has shown significant genome-wide linkage to premature myocardial infarction [26].

Approximately $90 \%$ of the $1 \mathrm{p}$ rearrangements are less than $10 \mathrm{Mb}$ in size [3], and it is assumed that quite a number of subjects are misdiagnosed [3]. Moreover, several subjects diagnosed with monosomy 1 p36 have been reported to have mild or atypical phenotypes or presenting features that overlap with other genetic syndromes [11,27-29].

In conclusion, our case reports confirm that some patients with 1 p36 monosomy may show a Prader-Willi-like physical phenotype and that this aspect may therefore be overlooked, which may result in this condition being underdiagnosed. These patients may show such characteristics as obesity with hyperinsulinism and impaired glucose 
metabolism. Further studies are necessary to further evaluate this aspect.

\section{Consent statement}

Written informed consent was obtained from the parents of the patients for publication of this case report and any accompanying images.

\section{Competing interests}

The authors declare that they have no competing interests.

\section{Authors' contributions}

SStagi carried out the endocrinological evaluation, conceived of the study and participated in its design. EL performed the clinical genetic diagnosis. SSeminara performed the endocrinological evaluation. MP performed the molecular genetic studies. FC participated in the endocrinological evaluation. MdM participated in the endocrinological evaluation and participated in its coordination. All authors read and approved the final manuscript.

\section{Author details}

'Health's Sciences Department, University of Florence, Anna Meyer Children's University Hospital, Florence, Italy. ${ }^{2}$ Genetics and Molecular Medicine Unit, Anna Meyer Children's University Hospital, Florence, Italy. ${ }^{3}$ Department of Paediatrics, University of Chieti, Chieti, Italy. ${ }^{4}$ Paediatric Endocrinology Unit, Anna Meyer Children's University Hospital, viale Pieraccini 24, Florence 50139, Italy.

Received: 10 June 2013 Accepted: 23 January 2014

Published: 30 January 2014

\section{References}

1. Shapira SK, McCaskill C, Northrup H, Spikes AS, Elder FF, Sutton VR, Korenberg JR, Greenberg F, Shaffer LG: Chromosome 1p36 deletions: the clinical phenotype and molecular characterization of a common newly delineated syndrome. Am J Hum Genet 1997, 61:642-650.

2. Heilstedt HA, Ballif BC, Howard LA, Kashorf CD, Shaffer LG: Population data suggest that deletions of $1 p 36$ are a relatively common chromosome abnormality. Clin Genet 2003, 64:310-316.

3. Battaglia A, Hoyme HE, Dallapiccola B, Zackai E, Hudgins L, MCDonaldMcGinn D, Bahi-Buisson N, Romano C, Williams CA, Brailey LL, Zuberi SM, Carey JC: Further delineation of deletion 1 p36 syndrome in 60 patients: a recognizable phenotype and common cause of developmental delay and mental retardation. Pediatrics 2008, 121:404-410.

4. Gajecka M, Mackay KL, Shaffer LG: Monosomy 1 p36 deletion syndrome. Am J Med Genet C: Semin Med Genet 2007, 145C:346-356.

5. Slavotinek A, Shaffer LG, Shapira SK: Monosomy 1p36. J Med Genet 1999, 36:657-663.

6. Shaffer LG, Heilstedt HA: Terminal deletion of 1p36. Lancet 2001, 358 Suppl:S9.

7. White PS, Maris JM, Beltinger C, Sulman E, Marshall HN, Fujimori M, Kaufman BA, Biegel JA, Allen C, Hilliard C, et al: A region of consistent deletion in neuroblastoma maps within human chromosome 1p36.2-36.3. Proc Natl Acad Sci U S A 1995, 92:5520-5524.

8. Thompson FH, Taetle R, Trent JM, Liu Y, Massey-Brown K, Scott KM, Weinstein RS, Emerson JC, Alberts DS, Nelson MA: Band 1p36 abnormalities and t(1;17) in ovarian carcinoma. Cancer Genet Cytogenet 1997, 96:106-110.

9. Kurosawa K, Kawame H, Okamoto N, Ochiai Y, Akatsuka A, Kobayashi M, Shimohira M, Mizuno S, Wada K, Fukushima Y, Kawawaki H, Yamamoto T, Masuno M, Imaizumi K, Kuroki Y: Epilepsy and neurological findings in 11 individuals with 1p36 deletion syndrome. Brain Dev 2005, 27:378-382.

10. Battaglia A: Del 1 p36 syndrome: a newly emerging clinical entity. Brain Dev 2005, 27:358-361.

11. D'Angelo CS, Da Paz JA, Kim CA, Bertola DR, Castro Cl, Varela MC, Koiffmann CP: Prader-Willi-like phenotype: investigation of 1 p36 deletion in 41 patients with delayed psychomotor development, hypotonia, obesity and/or hyperphagia, learning disabilities and behavioral problems. Eur $\int$ Med Genet 2006, 49:451-460.

12. Edwards KL, Wan JY, Hutter CM, Fong PY, Santorico SA: Multivariate linkage scan for metabolic syndrome traits in families with type 2 diabetes. Obesity (Silver Spring) 2011, 19:1235-1243.
13. Hoffmann K, Planitz C, Rüschendorf F, Müller-Myhsok B, Stassen HH, Lucke B, Mattheisen M, Stumvoll M, Bochmann R, Zschornack M, Wienker TF, Nürnberg $P$, Reis A, Luft FC, Lindner TH: A novel locus for arterial hypertension on chromosome 1 p36 maps to a metabolic syndrome trait cluster in the Sorbs, a Slavic population isolate in Germany. J Hypertens 2009, 27:983-990.

14. Hoffmann K, Mattheisen M, Dahm S, Nürnberg P, Roe C, Johnson J, Cox NJ, Wichmann HE, Wienker TF, Schulze J, Schwarz PE, Lindner TH: A German genome-wide linkage scan for type 2 diabetes supports the existence of a metabolic syndrome locus on chromosome $1 \mathrm{p} 36.13$ and a type 2 diabetes locus on chromosome 16p12.2. Diabetologia 2007, 50:1418-1422.

15. Stalker HJ, Keller KL, Gray BA, Zori RT: Concurrence of fragile $X$ syndrome and $47, X Y Y$ in an individual with a Prader-Willi-like phenotype. Am J Med Genet A 2003, 116A:176-178.

16. Monaghan KG, Van Dyke DL, Feldman GL: Prader-Willi-like syndrome in a patient with an Xq23q25 duplication. Am J Med Genet 1998, 80:227-231.

17. De Vries BB, Niermeijer MF: The Prader-Willi-like phenotype in fragile $X$ patients: a designation facilitating clinical (and molecular) differential diagnosis. J Med Genet 1994, 31:820.

18. Mitter D, Buiting $K$, von Eggeling $F$, Kuechler A, Liehr T, Mau-Holzmann UA, Prott EC, Wieczorek D, Gillessen-Kaesbach G: Is there a higher incidence of maternal uniparental disomy 14 [upd(14)mat]? Detection of 10 new patients by methylation-specific PCR. Am J Med Genet A 2006, 140:2039-2049.

19. Berends MJ, Hordijk R, Scheffer H, Oosterwijk JC, Halley DJ, Sorgedrager N: Two cases of maternal uniparental disomy 14 with a phenotype overlapping with the Prader-Willi phenotype. Am J Med Genet 1999, 84:76-79.

20. Bonaglia MC, Ciccone R, Gimelli G, Gimelli S, Marelli S, Verheij J, Giorda R, Grasso R, Borgatti R, Pagone F, Rodriguez L, Martinez-Frias ML, van Ravenswaaii C, Zuffardi O: Detailed phenotype-genotype study in five patients with chromosome $6 q 16$ deletion: narrowing the critical region for Prader-Willi-like phenotype. Eur J Hum Genet 2008, 16:1443-1449.

21. Eugster EA, Berry SA, Hirsch B: Mosaicism for deletion 1p36.33 in a patient with obesity and hyperphagia. Am J Med Genet 1997, 70:409-412.

22. Keppler-Noreuil KM, Carroll AJ, Finley WH, Rutledge SL: Chromosome 1p terminal deletion: report of new findings and confirmation of two characteristic phenotypes. J Med Genet 1995, 32:619-622.

23. D'Angelo CS, Kohl I, Varela MC, de Castro Cl, Kim CA, Bertola DR, Lourenço CM, Koiffmann CP: Extending the phenotype of monosomy 1 p36 syndrome and mapping of a critical region for obesity and hyperphagia. Am J Med Genet A 2010, 152A:102-110.

24. Tsuyusaki Y, Yoshihashi H, Furuya N, Adachi M, Osaka H, Yamamoto K, Kurosawa K: $1 \mathrm{p} 36$ deletion syndrome associated with Prader-Willi-like phenotype. Pediatr Int 2010, 52:547-550.

25. Rodríguez VR, Mazzucato LF, Pina-Neto JM: Lack of evidence for monosomy 1 p36 in patients with Prader-Willi-like phenotype. Braz J Med Biol Res 2008, 41:681-683

26. Province MA, Kardia SL, Ranade K, Rao DC, Thiel BA, Cooper RS, Risch N, Turner ST, Cox DR, Hunt SC, Weder AB, Boerwinkle E, National Heart, Lung and Blood Institute Family Blood Pressure Program: A meta-analysis of genome-wide linkage scans for hypertension: the national heart, lung and blood institute family blood pressure program. Am J Hypertens 2003, 16:144-147.

27. Neumann LM, Polster T, Spantzel T, Bartsch O: Unexpected death of a 12 year old boy with monosomy 1p36. Genet Couns 2004, 15:19-26.

28. Torisu H, Yamamoto T, Fujiwaki T, Kadota M, Oshimura M, Kurosawa K, Akaboshi S, Oka A: Girl with monosomy $1 \mathrm{p} 36$ and Angelman syndrome due to unbalanced der(1) transmission of a maternal translocation $\mathrm{t}(1 ; 15)(\mathrm{p} 36.3 ; \mathrm{q} 13.1)$. Am J Med Genet A 2004, 131:94-98.

29. Tan TY, Bankier A, Slater HR, Northrop EL, Zacharin M, Savarirayan R: A patient with monosomy $1 \mathrm{p} 36$, atypical features and phenotypic similarities with Cantu syndrome. Am J Med Genet A 2005, 139:216-220.

\section{doi:10.1186/1471-2350-15-16}

Cite this article as: Stagi et al:: Type II diabetes and impaired glucose tolerance due to severe hyperinsulinism in patients with 1 p36 deletion syndrome and a Prader-Willi-like phenotype. BMC Medical Genetics 2014 15:16 